\title{
An Assessment of Labour Availability in Major Coconut Growing Areas in Coconut Triangle
}

\author{
P M E K Pathiraja ${ }^{1}$, M T N Fernando ${ }^{2}$, A W A D R Abeysekara ${ }^{3}$, S D J N Subasinghe ${ }^{4}$ \\ ${ }^{1}$ Agricultural Economics Division, Coconut Research Institute, Lunuwila, Sri Lanka. Email: erandathiep@yahoo.com \\ 2Email:neilfrnnd@yahoo.com ${ }^{3}$ Email: rabeysekera@yahoo.com ${ }^{4} E m a i l:$ economics@cri.lk
}

\begin{abstract}
Scarcity of labour, increased labour charges and shortage of both skilled and unskilled labour have become a major issue for coconut growers. This study aimed to assess the current labour availability in coconut cultivation sector. A field survey was conducted from October to December 2005, focusing four major coconut growing areas in the coconut triangle namely Kurunegala, Kuliyapitiya, Marawila and Gampaha. The findings show that an acute laboure shortage is experienced by $23 \%$ and $21 \%$ of the respondents in Kuliyapitiya and Gampaha regions respectively. Generally, 65\% shortage in Gampaha, $60 \%$ in Kuliyapitiya, 50\% in Kurunegala and $27 \%$ shortage in Marawila were reported. An acute shortage for skilled labour necessary for harvesting was reported in Gampaha and Marawila whereas in other two areas it was for unskilled labour. Irrespective of the region, young generation's participation to the labour force was very poor. Generally, smallholders pay higher wage rates compared to estate sector. Skilled labour is 3 to 4 times highly paid compared to the unskilled labour in each region. In terms of wage rates a statistically significant gender disparity exists in each region favouring male labour. The findings suggest the need of inventing innovative mechanization technology in order to reduce the dependence on manual labour. The cost effectiveness of the mechanization technologies is also highlighted. A deep attitudinal change is a requisite to attract the young generation to cultivation sector and there is a possibility of reintroducing harvesting as a recognized commercial service by a company.
\end{abstract}

Key words: availability, skilled, acute shortage

\section{INTRODUCTION}

Coconut sector contributes $1.3 \%$ of the GDP in Sri Lanka and its export earnings in 2007 were US \$ 141.2 million (Central Bank of Sri Lanka, 2007). It provides employment for 500, 000 people both in the cultivation and processing sectors (National Plantation Industry Policy Framework, 2007). Around $20.6 \%$ of the total arable lands of the country are utilized for coconut cultivation(Dissanayake, 2005). The total coconut cultivated extent is about 394,837 ha $(975,245$ 
acres) and around $82 \%$ is small holdings while the rest is considered as the estate holdings (Sri Lanka Coconut Statistics, 2006). The main coconut growing areas are concentrated in the Puttalam, Kurunegala, Gampaha and Kaluthara districts which form the coconut triangle. These areas contribute to $61 \%$ of the total coconut extent constituting 34\% from Kurunegala, 12\% from Puttalam and 11\% from Gampaha district (Department of Census and Statistics, 2002).

Since last two decades, the coconut industry has been facing many problems, of which, the declining profit from coconut cultivation is notable.

The declining profit is due to increased cost of production fuelled by high cost of inputs, mainly fertilizer and labour. Contribution of labour cost to the cost of production is around $29 \%$. Apart from the cost, the labour availability in the coconut cultivation sector has shown a declining trend over the recent years irrespective of skilled or otherwise. The coconut growers complain of the shortage of labour and the rising labour costs.

The labour utilization in coconut cultivation sector is around 1 person per 4 ha (approximately10 acres) and it a much lower value with compared to the other plantation crops like tea and rubber (Mahindapala and Pinto, 1991). The absence of labour to cater this less labour intensive sector shows a huge drawback for the future of coconut industry.

The intensity of Labour shortage appears to be unevenly distributed among the different Coconut Development Officer's ranges (CDO ranges). Therefore, the present study has attempted to assess the regional variations of labour availability and labour cost in the coconut cultivation sector within the coconut triangle. The study further analyzes the prevalence of labour shortage in various labour activities in different regional management areas and in different land size classes. The influence of demographic factors in labour availability and possible solutions for labour shortage are also looked into.

\section{METHODOLOGY}

Primary data, comprising both qualitative and quantitative was collected using a pre-prepared questionnaire through a field survey conducted from October to December 2005, focusing on four major coconut growing areas/regions in the coconut triangle namely Kurunegala, Kuliyapitiya, Marawila and Gampaha.

From each region, 30 respondents were selected. This 30 is distributed among five CDO ranges. Six sampling units were randomly taken from each CDO range considering the land size class. These land size classes were 2 to 5 acres, 5 to 10 acres, 10 to 20 acres and greater than 20 acres. According to Census of Agriculture, 1982 lands were categorized into above broader categories. It shows around $57 \%$ of the holdings are less than 2 acres, $29 \%$ are 2 to 5 acres, $10 \%$ are 5 to 10 acres, $2.5 \%$ are 10 to 20 acres and the rest is greater than 20 acres. Less than 2 acres category was not taken for the sample, as the labour requirement is not considerable in those lands. The total sample size thus came to 119 .

As labour requirement is highly related with management practices the selected lands were categorized into three management levels namely, high, medium and low. The lands 
subjected to regular fertilizer application, proper land management practices like weeding, moisture conservation were considered as highly managed lands. The lands which are not regularly practiced above mentioned activities were considered as medium level and the lands which rarely practiced any of those activities were considered as poorly managed lands.

Graphical and tabular analyses were conducted to generate a general picture regarding the labour availability and its demography. An attitude scale was used in measuring the respondent's attitude towards labour availability according to their experience. There were five categories namely, very scarce, scarce, adequate, plentiful and very plentiful.

The demography of labour availability was analyzed considering young generation's participation trend to the labour force, gender composition, activity specific labour availability and skilled or unskilled nature of labour. Wage rate differences against these types of labour were considered. Further the geographical variation of wage rates and the average labour requirement per year in each region and variation of wage rates with respect to land holding size were analyzed.

\section{RESULTS AND DISCUSSION}

\section{Land management}

Management level of the land was decided by the number of agronomic practices adopted by the respondents in order maximize the yield. The labour requirement highly depends on level of management. Management levels of the selected sample are distributed as represented in Figure 1.

The income level of the farmer may affect the level of management. When other income sources exist the owner tends to manage his land well. It may be a result of that the income earned from coconut is not sufficient to manage the land well and at the same time satisfying the needs of the land owner.

\section{Labour availability}

Figure 2 shows the level of labour availability as reported by respondents in each region.

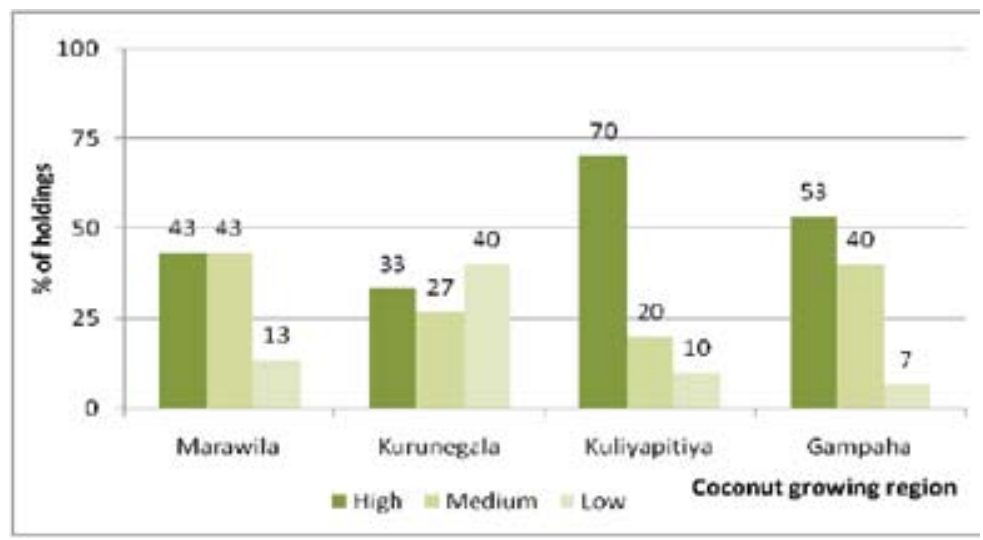

Figure 1: Management level of lands in each region 


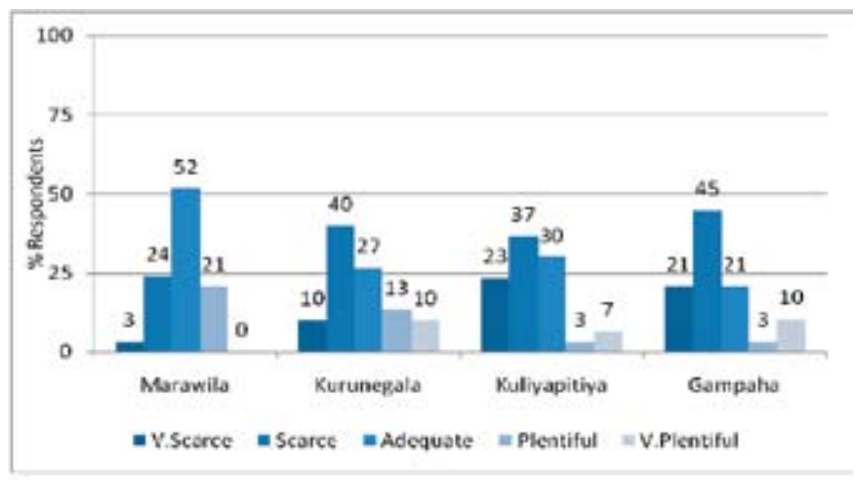

Figure2: Labour availability in coconut triangle

About $27 \%$ of the respondents experience a labour shortage in Marawila region while $73 \%$ had an adequate supply ${ }^{4}$. In Kurunegala, $50 \%$ of the respondents experience a shortage while the other $50 \%$ have an adequate labour supply. Interestingly, a substantial percentage of respondents in Kuliyapitiya and Gampaha regions experienced an acute shortage of labour, 23\% and $21 \%$ respectively. Equally, these two regions also experienced a relatively higher general shortage of labour, $60 \%$ and $65 \%$ respectively in Kuliyapitiya and Gampaha regions.

\section{Young generation's participation in the labour force}

Young generation's (age between 16 to 35 years) participation in the labour force crucially determines the potential future labour availability. Irrespective of the region, there was a significant reduction in young generation's participation in the labour force. The highest participation was from Kurunegala which is still as low as $33 \%$. It was $20 \%$ in Marawila, $14 \%$ in Gampaha and 7\% in Kuliyapitiya. The lesser the participation of young generation to the labour force, is likely to increase the cost of production.

\section{Gender- specific labour shortage}

In Marawila, Kurunegala and Gampaha, the percentage of respondents who experienced a gender-sensitive labour shortage was relatively less whereas it was high in Kuliyapitiya (Figure 3).

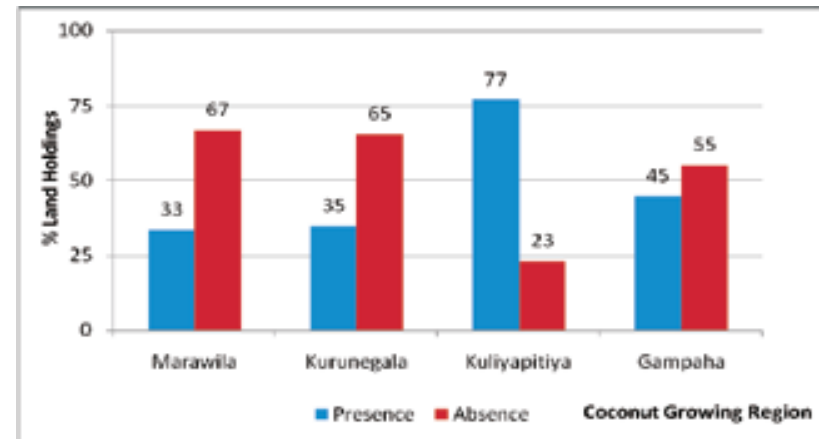

Figure 3: Gender variation in labour shortage ${ }^{5}$

\footnotetext{
${ }^{4}$ Since the percentage of respondents who indicated that the labour is very scarce is relatively less, this category was also considered together with the 'scarce' category.

${ }^{5}$ These values were obtained as a percentage of the respondents who experienced a labour shortage.
} 


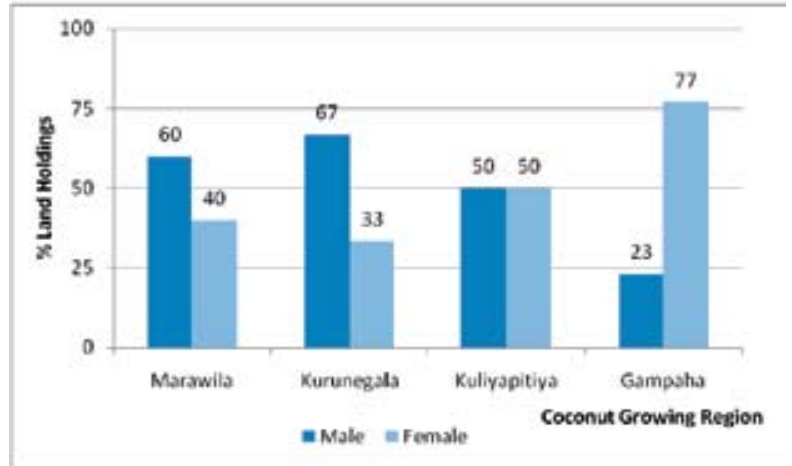

Figure 4: Regional occurrence of gender based labout shortage ${ }^{6}$

Figure 4 shows the shortage of labour by gender in each region. In Marawila and Kurunegala, male labour was of highly short and in Kuliyapitiya both male and female labour was of equally short. Conversely, in Gampaha region, $76 \%$ of the respondents experience a shortage in female labour. Part of the Gampaha region falls under the Export Processing Zone (EPZ) which provide employment for female in labour intensive garment factories. This is likely to be the reason for the acute female labour shortage reported in Gampaha region.

In each region, picking, climbing, and fencing are totally done by male labour. For weeding and manuring, female labour is more frequently used than male labour. Nut collection and manuring are equally shared by both male and female labour.
In coconut cultivation, skilled workers are paid higher rates than unskilled workers. Coconut harvesting (both by climbing and poles) and fencing are considered as skilled work while weeding and nut collection are considered to be unskilled work. The former work is exclusively male-dominated, due to hard nature while the latter work is generally done by women. This means that women tend to be involved in low-paid unskilled jobs in coconut cultivation, making them economically less empowered than men. Manuring is semi-skilled work which is equally shared by both male and female workers.

The highest wage rates $^{7}$ are recorded for both male and female labour in Gampaha region (Table 1).

Table 1: Geographical distribution of current actual wage rates by gender

\begin{tabular}{ccccc}
\hline Gender & Marawlla & Kurunegala & Kullyapltya & Gampaha \\
\hline \multicolumn{5}{c}{ Rs/MD or Rs.ND } \\
\hline Male & 269 & 257 & 269 & 300 \\
& $(57.31)$ & $(48.26)$ & $(57.01)$ & $(61.07)$ \\
\hline Female & 191 & 191 & 194 & 204 \\
& $(46.68)$ & $(27.01)$ & $(32.21)$ & $(39.93)$ \\
\hline
\end{tabular}

Notes: MD- Man Day (8 working hours), Figures in parentheses are standard deviations. WD- Women Day (8 working hours)

Source: Labour Survey (2006)

\footnotetext{
${ }^{6}$ As a percentage of the respondents who experienced a gender variation in labour shortage

7 These wage rates were the general average rates expressed by the respondents and it excludes the rates for skilled activities
} 
Table 2: Variation of wage rate according to land holding size

\begin{tabular}{lcccccccc}
\hline Land category & \multicolumn{2}{c}{ Marawila } & \multicolumn{2}{c}{ Kurunegala } & \multicolumn{2}{c}{ Kuliyapitiya } & \multicolumn{2}{c}{ Gampaha } \\
\hline & Rs./MD $^{8}$ & Rs.ND & Rs./MD & Rs. $N D$ & Rs./MD & Rs. $/ N D$ & Rs./MD & Rs. $N D$ \\
2 to $<5$ acres $^{9}$ & 285 & 190 & 289 & 210 & 311 & 211 & 325 & 212 \\
$>$ or $=5$ and $<10$ & 265 & 212 & 255 & 215 & 290 & 200 & 316 & 225 \\
$>$ or $=10 \&<20$ & 300 & 212 & 250 & 187 & 237 & 192 & 300 & 200 \\
$>$ or equal 20 & 237 & 171 & 228 & 162 & 234 & 178 & 263 & 188 \\
\hline
\end{tabular}

Source: Labour survey (2006)

The pressure exerted by the higher wages in industrial sector labour in Gampaha area raises the price of agricultural labour also upwards, making the coconut cultivation a competitive enterprise.

The regional differences are not statistically significant for both male and female labour. In all the four regions male labour is paid more compared to female labour which was statistically significant. (Female wage rate is 26 to $32 \%$ less than the male wage rate). This shows the existence of gender inequity in terms of wage rates in coconut cultivation sector. This is inevitable due to nature of work.

Table 2 shows the variation of labour wages in each region according to the land size class.

Across all four regions, there is a modest reduction in both male and female wage rates with increase in land size. Tendency for use of permanent labour by larger estates may be the reason for this. This implies that the smallholders have to pay higher rates compared to the estate sector. According to Agriculture Census (2002), nearly $81.9 \%$ of the national coconut extent is comprised by smallholdings (Dissanayake, 2005). This would mean that the majority of the coconut growers have to pay higher rates for labour.

\section{Activity wise labour shortage in each region}

The regional variations in labour shortage for different kinds of activities are shown in Figure 5. In Marawila and Gampaha regions, the highest shortage is for skilled labour such as picking by both bamboo poles and climbing. Around $70 \%$ of the respondents experienced a shortage for picking by bamboo poles and around $18 \%$ for both by pole harvesting and climbing. Altogether in Marawila around $88 \%$ of the respondents experienced a shortage for harvesting. In Gampaha region the corresponding figure was $69 \%$.

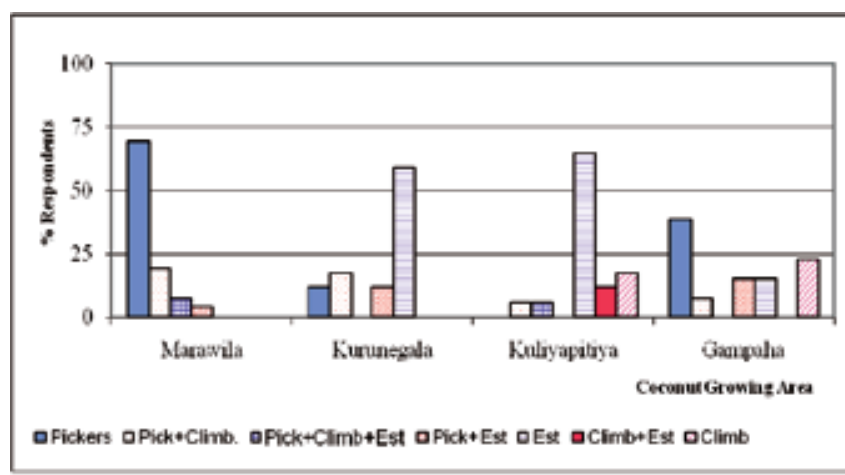

Figure 5: Acitivity wise labour shortage in each region

\footnotetext{
${ }^{8} \mathrm{MD}$ means man days while WD refers to women days.

${ }^{9} 1$ ha $=2.47$ acres
} 
In Kurunegala, around $29 \%$ of the respondents had shortage for skilled labour while in Kuliyapitiya region it was around $23 \%$. Kuliyapitiya and Kurunegala regions experience a notable shortage for labour required for estate work than in the other two regions.

\section{Wage rates}

The annual average daily wage rate for a male worker for coconut sector is Rs. 378 in 2005 and Rs.411 in 2006 (Central Bank, 2006) and these wage rates are higher than that of tea and rubber. Female wage rate for coconut is not mentioned considering women are less involved in coconut sector activities.

It is observed that wage rates are not consistent with respect to each activity. Generally it is expected that skilled labour is highly paid compared to unskilled labour. Table 3 consists of average wage rates in each region for different activities.

Picking both by poles and climbing being skilled activities are paid higher wages. Other activities are paid comparatively low wage rates and among them manuring is fairly high. This pattern is observed in all the regions.
In Kurunegala region, mauring is less paid compared to the other regions. It is observed that $2 / 3$ of the labour used in this region for manuring is female labour which is cheaper than male labour.

\section{Labour turnover}

A labour study conducted in two villages in Laguna in Philippines (Cornista, 1984) showed that the labour availability is worse-off among the coconut growers. In those two villages, coconut labourers were relatively young with an educational attainment of below elementary level. It shows that educated and skilled (experienced) work force does not remain in coconut sector as they have more opportunities. In a developing economy it is expected to have the mobility of agricultural labour to the industrial and service sectors. Figure 6 describes the reasons ${ }^{10}$ for labour turnover in each region.

Low wage rate in estate work is a major cause for labour shortage in all the regions. Non-farm employment opportunities provide them with higher wages. Educational attainment is a cause for moving away from estate sector. This is notable in Marawila and Gampaha regions. Poor social acceptance of estate manual

Table 3: Variation of wage rate in relation to activities

\begin{tabular}{lcccc}
\hline & \multicolumn{4}{c}{ Marawila KurunegalaKuliyapitiya Gampaha } \\
\hline \multicolumn{1}{c}{ Activity } & RS/MD & RS/MD & RS/MD & RS/MD \\
& & & & \\
Picking & 619 & 771 & 610 & 647 \\
Climbing & 858 & 805 & 903 & 1141 \\
Nut Collection & 216 & 268 & 185 & 202 \\
Weeding & 194 & 163 & 216 & 209 \\
Manuring & 354 & 198 & 353 & 421 \\
Fencing & 216 & 203 & 317 & 247 \\
Average & 410 & 401 & 431 & 478 \\
\hline
\end{tabular}

Source: Labour survey (2006)

${ }^{10}$ Land owners' view 


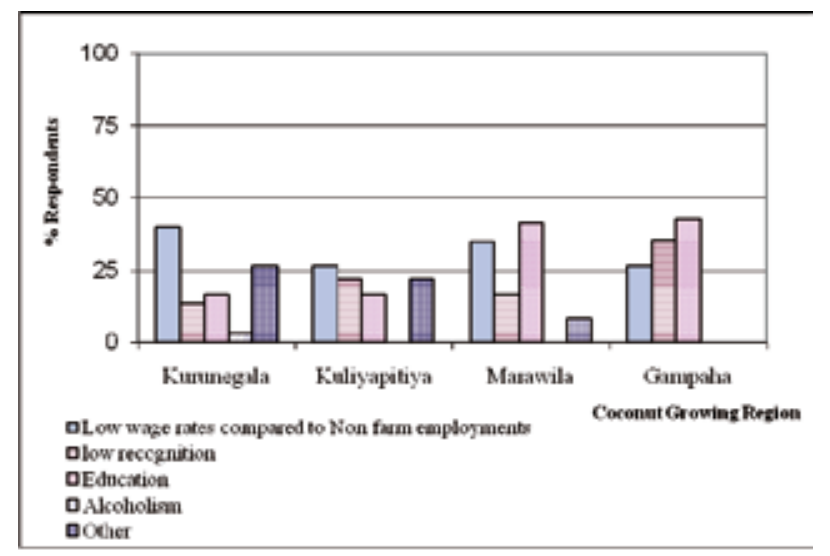

Figure 6: Reasons for labour turnover

labour workers is one of the major causes for poor participation of young generation. A deep attitudinal change is needed to improve the young generation's participation. If cost effective machineries can be introduced it will help to attract young generation. There is seasonality in labour availability in Kurunegala and Kuliyapitiya regions during the paddy harvesting and sowing times.

\section{Labour use pattern in different regions}

The efficiency of agricultural labour has become a critical issue in many countries. Poor labour productivity is a cause for increased cost of production. A study conducted by Sivaram (1996) on productivity improvement and labour relations in the tea industry in South Asia revealed that the productivity of a tea estate depends on the levels of labour utilization and the labour per unit area appropriate to the different levels of yield. He found that this requirement varies from country to country as well as district to district within the same country. For a well-managed estate, labour productivity is an important factor for cost minimization. Table 4 shows the labour - land ratio of each region.

Table 4: Labour - land ratio in each region

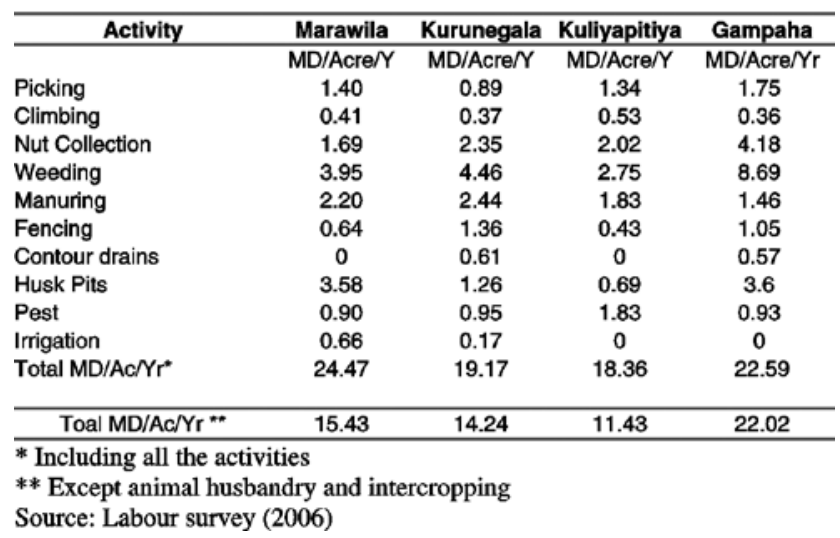


Table 5: Machinery use by the respondents in different region

\begin{tabular}{lcccc}
\hline \multirow{2}{*}{\multicolumn{1}{c}{ Actlvlty }} & \multicolumn{4}{c}{ \% Machinery Use } \\
\cline { 2 - 5 } Picking & Marawlla & Kurunegala Kullyapltlya & Gampaha \\
Climbing & - & & & \\
Nut Collection & - & & 83 & 83 \\
Weøding & 50 & 37 & 60 & 34 \\
Manuring & 15 & 5 & 23 & 4 \\
Contour drains & - & 50 & 100 & - \\
Husk Pits & 36.36 & 89 & 88 & 67 \\
Pest & - & - & 0 & - \\
Irrigation & 67 & - & 40 & - \\
\hline
\end{tabular}

Source: Labour survey (2006)

Irrespective of the region, highest labour requirement is for weeding and lowest for climbing. Although weeding is a labour intensive activity, this is being partly mechanized by the wide use of grass cutters especially in medium and higher income coconut lands. Average labour requirement for a well-managed acre of land $^{11}$ is 15 man-days in Marawila region, 14 in Kurunegala region, 11 in Kuliyapitiya region and highest is for Gampaha region, which is of 22 man-days. Machinery use may reduce the total man days required.

\section{Machinery Use}

Machineries are a substitute for manual labour. When machinery use is economical it can be used as a solution for labour shortage. Table 5 shows the machinery use of respondents in each region.

About $50 \%$ of the respondents in Marawila region use machineries for weeding. This is $60 \%, 34 \%$ and $30 \%$ respectively in Kuliyapitiya, Gampaha and Kurunegala regions. Machinery use for husk pits in Kurunegala and Kuliyapitiya regions was $89 \%$ and $88 \%$ respectively. In
Gampaha region $67 \%$ and in Mrawila region $36 \%$.

Use of machineries for contour drains is $100 \%$ in Kuliyapitiya and $50 \%$ in Kurunegala. The level of machinery use is not much different in all the regions. Husk pits are rarely practiced in Gampaha. Nut collection is a manual activity and supported by machineries in transporting nuts within the estate.

\section{Labour Costs}

Number of man-days required, frequency of practicing and wage rates affect the labour cost in a given holding. Table 5 shows the labour costs incurred in each activity as a percentage of total labour cost and its regional variation.

In Kurunegala district, the highest proportion of the labour cost was for nut collection and weeding. In Marawila, it was for picking followed by manuring.

\footnotetext{
${ }^{11}$ A land which ptractice all the activities mentioned in the table.
} 
Table 6: Proportion of labour cost for each activity from the total labour cost

\begin{tabular}{lrrrr}
\hline Activity & Kurunegala & Marawila & Kullyapitiya & Gampaha \\
\hline Picking & 15.83 & 26.44 & 30.40 & 20.3 \\
Climbing & 4.45 & 5.35 & 6.90 & 3.41 \\
Nut Collection & 28.99 & 12.95 & 13.22 & 19.03 \\
Weeding & 27.46 & 18.99 & 17.54 & 32.3 \\
Manuring & 14.82 & 23.22 & 20.31 & 9.75 \\
Fencing & 4.82 & 0 & 4.36 & 13.45 \\
Contour drains & 0.00 & 0 & 0.00 & 0.51 \\
Husk Pits & 1.72 & 6.98 & 2.35 & 0.69 \\
Pest & 1.25 & 2.64 & 4.65 & 0.4 \\
Irrigation & 0.08 & 1.12 & 0.27 & 0.16 \\
\hline
\end{tabular}

Source: Labour survey (2006)

The majority of the respondents in Marawila region practice manuring and it would be a cause for this. Kuliyapitiya region shares commonalities with the Marawila region.

In Gampaha it is for picking and nut collection. Generally weeding, picking, nut collection and manuring are the activities for which a considerable amount of costs are incurred. Therefore, mechanization possibilities should be explored for these activities.

\section{Diversity of labour}

Coconut harvesting is being a skilled labour involved activity, is mainly of contract nature in each region. The pole pickers are paid per acre or the climbers are paid per palm. Pole picking is the most regularly practiced method to climbing.

In all the regions contract labour is the only source except a little deviation in few respondents (Figure 7 and 8). This observation shows a possibility of emerging an organized system for skilled labour provision. A company can act as a service provider.

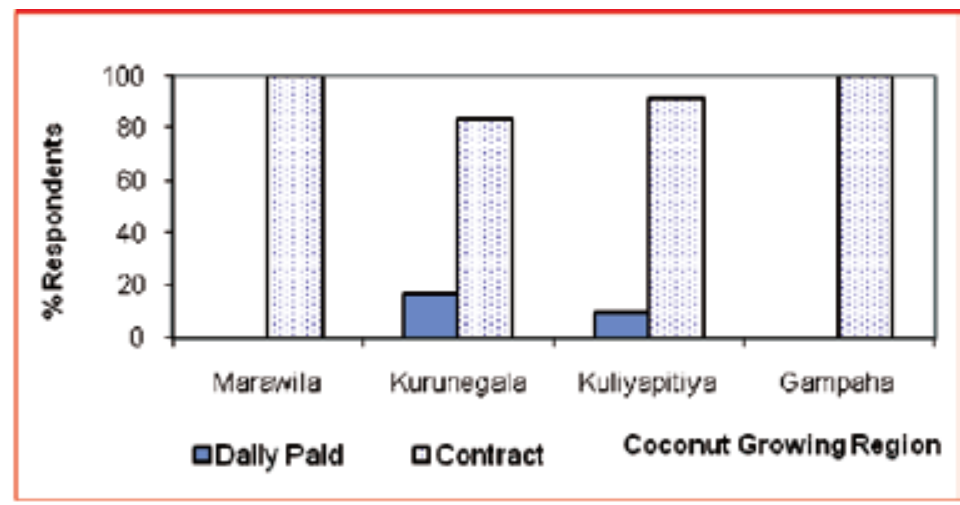

Figure 7 : Arrangement of labour for climbing 


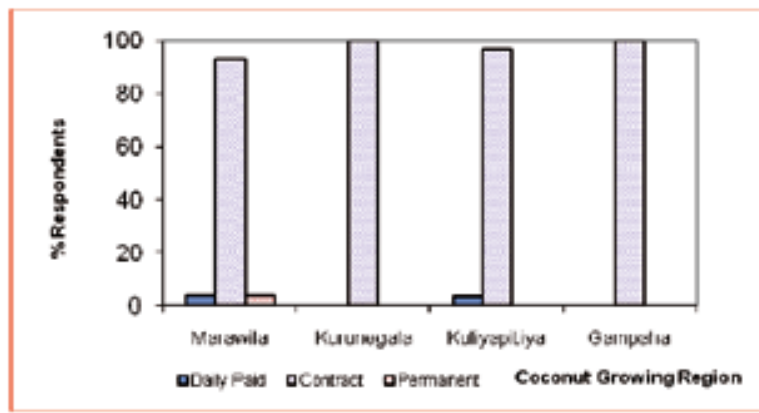

Figure 8: Arrangement of labour for pole picking

Fencing is not routine and it is occasional. In all the four regions majority of the respondents use daily paid labour. The next widely used type of labour is permanent labour except for Kurunegala region. The next category is family labour and in all the four regions family labour has a contribution for fencing.

Weeding is routinely practiced in twice or thrice a year. It is partially mechanized by a considerable number of respondents. Irrespective of the region daily paid labour is frequently used (figure 9).

About $21 \%$ of the respondents in Kurunegala region use family labour and in Gampaha,
Marawila and Kuliyapitiya corresponding figures are $14 \%, 10 \%$ and $6 \%$ respectively.

Manuring is done once or twice a year and it is well practiced in highly managed lands. In all the four regions, nearly $50 \%$ of the respondents use daily paid labour. Nearly $22 \%$ of the respondents each in Marawila and Kurunegala, and $27 \%$ in Kuliyapitiya region use contract labour. In Gampaha region, nearly 31\% of the respondents use permanent labour and for Marawila and Kuliyapitiya figures are 11\% and $4 \%$. Generally, there is a very low usage of family labour for manuring, which was 10\%, 5\% and 4\% respectively in Kurunegala, Gampaha and Kuliyapitiya regions. (figure 10)

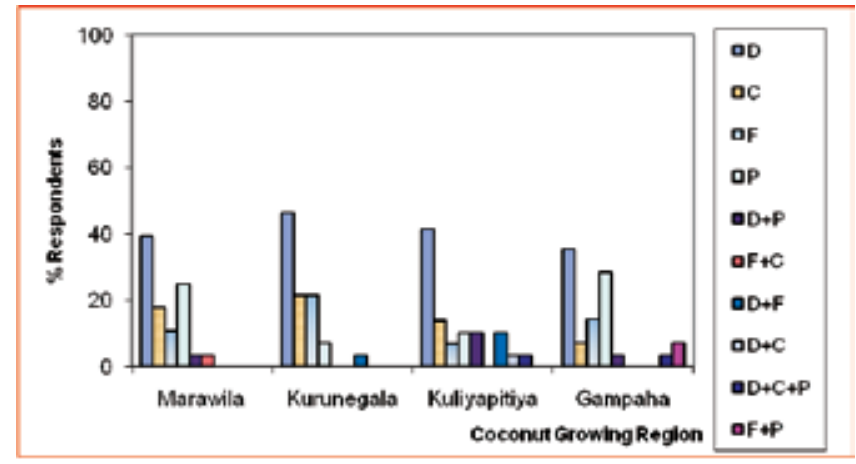

Figure 9: Different types of labour arrangement for weeding C-contract, D-daily paid, F-family, P-permanent 


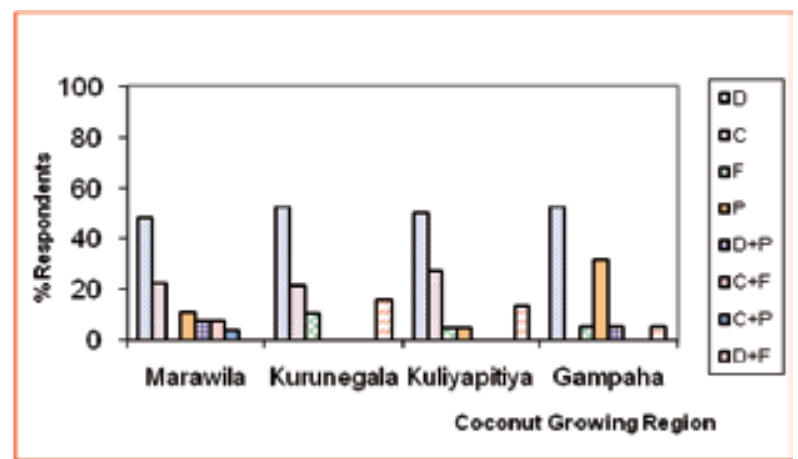

Figure 10 : Nature of labour used in fertillizer application

C-contract, D-daily paid, F-family, P-permanent

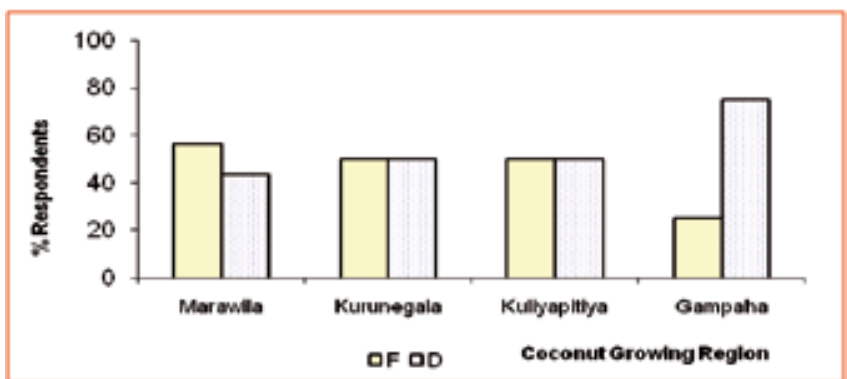

Figure 11: Different labour arrangements for animal rearing

Animal rearing is poorly practiced in all the regions. It has a daily labour requirement. In Gampaha region, $75 \%$ of the respondents use permanent labour and $25 \%$ use family labour. In all other regions family labour and permanent labour are used in equal percentages. It is being a labour-intensive activity; engagement of hired labour may not be economically worthwhile. (Figure 11)

Intercropping is practiced in Kurunegala and Gampaha regions (nearly 65\%) while in others poorly practiced. In Marawila, $50 \%$ of growers use family labour (Figure 12).

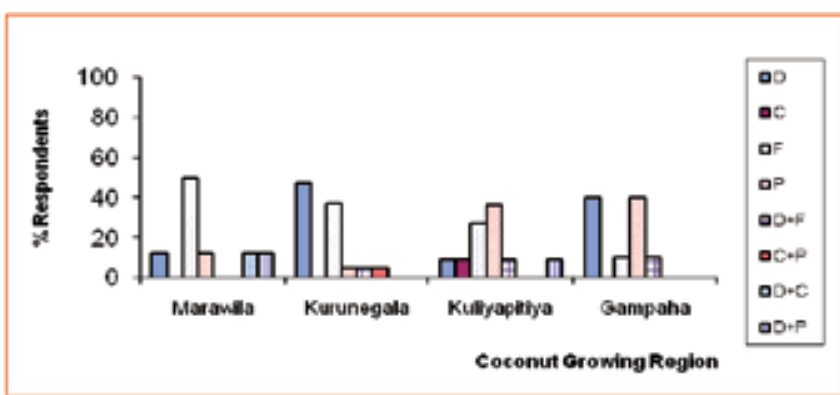

Figure 12 : Nature of labour use in intercropping 


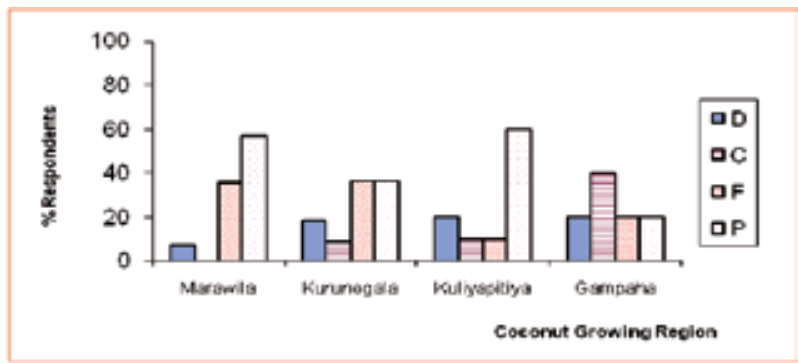

Figure 13: Nature of labour use in pest management

Except in young plantations and under planting, pest management is required when a pest attack or a threat arises. Therefore, daily paid labour is not an economical source for this activity in most of the occasions.

This activity involves an expertise knowledge, which requires for correct identification of the damage and appropriate management approach. Some land owners pay incentives for permanent labourers in their estates when they collect insects. Most of the respondents ignore mite control measures as those were labour demanding and not economical according to their point of view.

Except in Gampaha region permanent labour is frequently used in other regions. In Gampaha region contract labour is used by $40 \%$ (figure 13).

\section{CONCLUSION}

A substantial percentage of respondents in Kuliyapitiya and Gampaha regions experienced an acute shortage of labour (23\% and $21 \%$ respectively). It was around $10 \%$ in Kurunegala region. Shortage was not severe in Marawila region which may be due to the availability of refugees in some areas. An acute shortage for skilled labour necessary for harvesting of coconuts, both climbers and pole harvesters, was reported in Marawila and Gampaha regions despite the fact that a higher wage is paid. This is partly because the new generation is unwilling to take up this job due to social stigma. Irrespective of the region, there is a significant reduction in young generation's participation in the labour force. Highest was reported for the Kuliyapuitiya region. A deep attitudinal change should be introduced to the younger generation to promote their participation in cultivation labour market. Incentive systems should be introduced to the plantation sector to minimize the labour turnover.

A programme should be initiated to train a new generation of coconut harvesters and to provide an insurance scheme for them. A company can reintroduce coconut harvesting as a recognized commercial service.

Low wage rates, high education level and poor social acceptance were the causes for labour mobility from cultivation sector to other sectors.

In Kurunegala and Kuliyapitiya regions unskilled labour is of highly short compared to other regions. Skilled labour is highly paid compared to unskilled labour and it is frequently of contract type. Activities involving skilled 
labour are male dominated while activities involving unskilled labour are female dominated. This means that the employment opportunities in the coconut cultivation sector unequally empower the men and women in terms of earning possibilities favouring the men.

A disparity exists between male and female wage rates. It is likely to be that the small holders have to pay higher wage rates compared to estate sector.

Husk pits, contour drains and weeding are the activities with a greater tendency to

\section{REFERENCES}

Central Bank of Sri Lanka, (2007). Annual Report. Colombo.

Cornista,L.B (1984), The coconut agricultural labourers in two villages in Laguna. The Philippine Journal of Coconut Studies. IX, $1 \& 2$. Pp

Department of Census and Statistics, 2002. Coconut Extent. Colombo, Sri Lanka.

Dissanayake, A. M.U, (2005). Progress of Coconut Cultivation, 1962- 2002. Department of Census and Statistics, Colombo, Sri Lanka. be mechanized. Innovative mechanization technology should be invented to reduce the dependence of manual labour in cultivation related activities.

\section{ACKNOWLEDGEMENTS}

Authors thank the Director of CRISL for facilitating this research. The support extended by the Deputy Director (Research), CRISL, the staff of the Agronomy and Agricultural Economics Divisions is highly appreciated.

Mahindapala, R., Pinto,J.L.J.G. , (1991). Coconut Cultivation. Coconut Research Institute of Sri Lanka, Lunuwila. Pp 3.

Sivaram, B. (1996). Productivity improvement and labour relations in the tea industry in South Asia. http://www.ilo.org/public/ english/dialogue/sector/ papers/ proschem/ index.htm.

CoconutDevelopmentAuthority,2006. SriLanka Coconut Statistics, Coconut Development Authority, Colombo, Sri Lanka. 